\title{
PROTECTION OF CULTURAL HERITAGE IN URBAN AREAS DURING PEACE AND CONFLICT TIMES FROM THREATS TO RISK PREPAREDNESS AS A SHARED RESPONSIBILITY
}

\author{
C. Cimino
}

WATCH, Via Francesco Dall'Ongaro no. 62 -00152 Roma, Italy - c.cimino@eyeonculture.net

KEY WORDS: 1999 Second Protocol to the Hague Convention, Risk Cycle Models, Risk Preparedness Plans, Response, Civil Military Cooperation, 1999HP Guidelines, Public Awareness Promotion, Protocols of intervention.

\begin{abstract}
:
In times of economic hardship, the support given by specialized civil society organisations to public institutions in the protection of cultural heritage has often proved very useful, and there is evidence that their contribution is essential in times of conflicts and natural disasters, if well-designed plans and measures are organized efficiently, thoroughly tested and properly implemented.

The 1954 Hague Convention for the Protection of Cultural Property in the Event of Armed Conflict (HC), its two Protocols and other international juridical instruments address these situations since decades, however, they remained widely not-applied in absence of proper regulatory instruments. In 2004, the Second Protocol of the Hague Convention (1999HP) entered into force and the Committee of the State Parties was formed. It became clear that a new trend started when, in 2009, draft Guidelines for the implementation of the 1999HP were issued. Meanwhile, WATCH, in partnership with the Council of the United Municipalitities of Jbail (Lebanon) and the Head of the Municipality of Mtskheta (Georgia) prepared a project proposal aimed to set a precedent in the governance of urban sites that are registered in the World Heritage List which are at risk of armed conflict.

The project War Free World Heritage Listed Cities www.warfreeheritage.net was co-financed in 2010 with a grant within the framework of the EC CIUDAD programme and it is currently at an advanced level of implementation. This presentation will focus on achievements and contingencies faced during implementation as well as lessons learned that could be surely useful for pers pective applicants.
\end{abstract}

\section{NOMINATION OF WORLD HERITAGE SITES TO THE STATUS OF ENHANCED PROTECTION. TWO CONCRETE CASE STUDY}

The review of the 1954 Hague Convention for the Protection of Cultural Property in the Event of Armed Conflict and its first Protocol by P. Boylan in 1993 has conducted to the formulation and the approval in 1999 of the Second Protocol to the Convention (1999 HP). In 2004, the Second Protocol entered into effect and the Committee for the Protection of Cultural Property in the event of Armed Conflict (1999 HP Committee) was created and it met for the first time in 2006. It became clear at that point the shift in trends and the crescendo in momentum of the Convention, thus the idea of a project for the implementation of the 1999 HP with a participatory approach in line with the current trends of decentralised policies came up and developed through the current days.

\section{IS WAR EVER CONSIDERES BY URBAN PLANNERS?}

Urban planners are not taught to design cities thinking of them under a state of war and, their vision is rather focused on the city to be for people who live in community. Shared spaces and private spaces, spaces of inclusion and integration are designed and realised today possibly with enough vision to meet the needs of a community in evolution today with an eye looking to the future. However, surely defensive cities designed to resist war or to contain its effects and protect people and goods are today considered urban history and war is not accounted today. Warfare currently available has reached such a level of diversification and destructive potentials that practically no human settlement could resist.

Land use plans, Master plans, Regulatory policies, etc. are instruments that in most cases do not contain provisions to enforce during times of peace to prevent or minimise the effects of an eventual armed conflict. Urban heritage sites are normally lively inhabited, located mostly at the core of wider urban contexts vibrating of life and exposed to trends imposed in modern cities.

Planners dealing with ancient or historic cities work at the rehabilitation and conservation of these urban structures and their townscape to harmonise ancient and new for the satisfaction of the current living standards addressing many impelling priorities including mobility, waste management, infrastructure, etc. that, in cases of war, could often turn often factors of threat.

Thus, if the mix between old and new is not properly balanced, in case of war, urban heritage sites could easily turn into military targets. With this assumption in mind, in 2008 , soon after the advanced draft of the Guidelines* for the implementation of the 1999HP was circulated, WATCH considered the case of urban heritage management in critical times as one of the priorities to address. The rationale after this choice is that in a living heritage settlement are normally found concentrated archaeological or historic sites, monuments, museums collections, all kind of movable heritage, archives, libraries, and much more. The overall idea was that starting with a concrete experience on urban sites would help in the definition of appropriate risk preparedness, response and mitigation measures for a greater variety of case scenarios. An idea that developed into War Free World Heritage Listed Cities WFWHLC (www.warfreeheritage.net) a project aimed to propose a model for international cooperation in the implementation of the 1954 Hague Convention and was co-financed in 2010 with a grant from

\footnotetext{
* UNESCO. Guidelines for the Implementation of the 1999 Second Protocol to the Hague Convention of 1954 for the Protection of Cultural Property in the Event of Armed Conflict. http://unesdoc.unesco.org/images/0018/001867/186742E.pdf
} 
the EU within the ENPI CIUDAD regional programme. A question of shared responsibility for the protection of natural and cultural sites listed within the world heritage list that reached currently an advanced level of implementation. Byblos (Lebanon) and Mtskheta (Georgia), the two world heritage sites beneficiaries of the project are both embedded within their historic core city centre and are quite different in terms of their urban fabric, territorial history and demographic consistencies.

After over three years of activity an international workshop hosted at the University La Sapienza in Rome 16 and 17 May 2013 was organised by WATCH and gathered project partners and associates of the Council of the United Municipalities of Jbail (Lebanon), Head of the Municipality of Mtskheta (Georgia), NEREA* (Italy) and FOCUH ${ }^{* *}$ (Turkey), together with representatives from the Georgian Ministries of Culture, Defence, Interiors and the Municipality of Mtskheta, members of an Advisory Board including UNESCO, ICCROM, the Austrian Army and the International Institute of Humanitarian Law (IIHL) and other international experts who met during a very intense two days action.

The workshop was designed to bring around a table experts from a multidisciplinary arena to discuss, review, integrate and//or highlight eventual gaps to be filled in the documentation, records acquired, studies conducted and plans made to satisfy the provisions of the 1999 Second Protocol to the Hague Convention for the Protection of Cultural Property in the Event of Armed Conflict for the nomination of the two cultural heritage sites to the status of enhanced protection. A priority of the workshop was to verify how the prescriptions of the 1972 World Heritage Convention with those of the 1954 Hague Convention and its two protocols were reconciled in compliance with the more applicative articles 54 through 62 of the Guidelines issued by the 1999HP Committee.

Three thematic tables were set for a deeper and more specialised review of the materials available focusing on:

1. Urban planning and protective measure for heritage sites embedded within the ancient/historic core city centres;

2. Reconciliation of national laws with the 1999 Second Protocol to the Hague Convention;

3. Administrative and emergency measures in place for the protection of movable heritage

Inputs were given by the participants to the workshop highlighting a variety of issues that are relevant for the improvement of the dossiers being prepared for the two world heritage sites. Between those elements emerged, some minor legislative upgrading resulted to be still necessary, especially to better specify existing legislation vis-a-vis some interpretation issued by the 1999HP Committee on the subject (e.g. criminal law). The need for a firmer implementation of urban regulatory policies was highlighted to match with the requirements set for the world heritage sites, especially as far as the impact caused by some recent urban development. An overall improvement of the state of heritage sites management is required despite some concrete measures were already undertaken by the concerned authorities both in Lebanon and Georgia.

While the completion of draft dossiers based on the 1999HP for the enhanced protection of the two World Heritage Listed sites exposed to immediate threat in case of armed conflict in

\footnotetext{
* Friends of Cultural Heritage Association

** Network for Advanced Technologies in Cultural Heritage
}

Lebanon and Georgia represents the overall objective of the project, its specific objectives are:

- To complete pilot multidisciplinary studies on two world heritage listed cities/sites that are finalised to conduct Risk assessment, as well as to define Risk preparedness/Response and Mitigation measures in line with $1954 \mathrm{HC}$, its two protocols and also other relevant conventions and international laws;

- To support local and national authorities to create awareness and promote concrete actions towards the ratification of the 1999HP;

- To secure sustainability and set measures for expost Risk Preparedness Plans monitoring/ upgrading/updating.

\section{METHODOLOGY}

The very different and articulated list of topics to be considered for the protection of cultural heritage sites within urban areas in times of armed conflicts were addressed with urban planners' approach in an effort to reconcile the provisions contained in the Second Protocol and the related Guidelines with the visions for the future of the urban sites that are expressed in the various urban planning and management instruments. Thus, War Free World Heritage Listed Cities Project objectives were since conception designed to be reconciled with the provisions of the 1999HP as follows:

- To design Risk Preparedness Plans for cultural heritage at threat of conflict:

Through concept studies for risk assessment and analysis, Design risk mitigation policies, Risk Management.

(1999 HP, Article 2 Relation to the Convention)

- To promote institutional capacity development: Through establishing inter institutional response units, work-frames and protocols of intervention. (1999 HP, Article 41 Ratification, acceptance or approval, Article 42 Accession)

- To train qualified national experts:

Responsible multidisciplinary, inter-institutional coordinated HR trained to integrate Risk Management Units in each country .

(1999HP, Article 5 Safeguarding of cultural property)

- To develop public awareness instruments: Participatory approach as a factor of risk management.

(1999HP Guidelines, Article 13 Awareness and 30 Dissemination)

- To produce two draft dossiers:

For the candidacy to the status of enhanced protection for the Heritage Listed Sites of the cities of Byblos (Lebanon) and Mtskheta (Georgia). This last objective is in line with UNESCO call on State Parties in the 1999HP for the nomination of natural and cultural heritage sites to be protected.

\section{ABOUT CONCEPT STUDIES}

Concept studies is a definition used to label all those activities conducted during the project which through survey, risk identification, assessment and analysis, definition of risk mitigation measures and comprehensive risk management 
planning would conduct to modelling for the final design of Risk Preparedness Plans (RPP) for the cities of Byblos and Mtskheta. Than concept studies in this project are like concept drawings for industrial designers. In this specific case concept studies is a wording applied to design plans modelled on the very peculiar characteristics typical and unique of each world heritage site. In other words plans that incorporate those factors of uniqueness and apply only to that specific site and the environment it lays in.

The following queries are examples of those that were addressed within the concept studies:

\begin{tabular}{|cl|}
\hline 1. & $\begin{array}{l}\text { Is a Review/Validation/Change of urban plans } \\
\text { needed? }\end{array}$ \\
\hline 2. & $\begin{array}{l}\text { Is a Review/Validation/Change of the } \\
\text { law/regulatory policies needed? }\end{array}$ \\
\hline 3. & $\begin{array}{l}\text { Is change of locations for movable heritage at risk } \\
\text { possible/needed? }\end{array}$ \\
\hline 4. & $\begin{array}{l}\text { Are issues concerning delegation/endorsement of } \\
\text { duties (Who does what before during after crisis) } \\
\text { addressed? }\end{array}$ \\
\hline 5. & $\begin{array}{l}\text { Better emergency planning or planning for } \\
\text { emergency? }\end{array}$ \\
\hline 6. & $\begin{array}{l}\text { Are there conditions for setting Risk Management } \\
\text { Units (RMU) \& supporting groups? }\end{array}$ \\
\hline 7. & $\begin{array}{l}\text { Are there the conditions of access for International } \\
\text { Inspectors to monitor the level of maintenance of } \\
\text { security conditions and updating of the RPP? }\end{array}$ \\
\hline 8. & $\begin{array}{l}\text { Are there the conditions for relocation of Military } \\
\text { sites, Weapons, and Warfare, if any, in general } \\
\text { threatening Heritage sites? }\end{array}$ \\
\hline
\end{tabular}

Table 1. Queries addressed within the concept studies

Answers to these and several other queries conducted to the definition of a rational grid of reference where each of the answers found contributes to clarify which are the factors posing threats and, per each of these threats, a value will is expressed turning the perceived factors of threat into measured risk according to set criteria.

The concept studies are being currently completed as a focal activity of the project. The conditions of threats existing (or pending) on the ground in both cities were assessed and recorded through direct survey and experts' desk review.

Conditions of threat referred here are all those physical, normative, behavioural, structural or infrastructural situations that could cause (or legitimate) the intervention of an hostile armed force to target the two world heritage sites addressed by the project.

A final matrix of reference where threats are turned into quantity/quality risk factors that will be matched by provisions of set proportional responsive measures will be elaborated at a later stage within a multidisciplinary framework, driving to the definition of measures to be undertaken and protocols for the maintenance of the safety conditions for the two world heritage sites. Relevant components addressed within the project implementation include:

- Risk assessment through multidisciplinary experts' on site survey, desk review, audit and analysis of existing legal, administrative, managerial and security conditions and identification of eventual - blunt or hiding critical weaknesses;

- Risk Preparedness Plans including response and mitigation management measures set for the protection of the sites before/during armed conflicts designed and ready for implementation;

- Promotion of a sustainable widespread awareness among civil and military population about the needs of protection of the World Heritage sites according to the 1954 $\mathrm{HC}$;

- Training for the military and the civil authorities and experts in both countries on the existing international legislation and conventions for the protection of cultural heritage in times of conflict with a particular focus on the 1954 Hague Convention and its two Protocols as well as other relevant jurisprudence directly or indirectly associated;

- Draft dossiers for Byblos and Mtskheta Listed Heritage enhanced protection to be endorsed by the project to the respective concerned national High Contracting Parties in Lebanon and Georgia for their final submission to the 1999 HP Secretariat at UNESCO.

The methodology adopted for the implementation of WFWHL includes a complete set of activities conducted on site and in remote modality with support by all the experts participating in the project. A chain of progressive declinations of risk was followed in the risk assessment keeping in mind that in our case the assessment of the existing risk factors for the selected cultural heritage sites makes reference to a risk cycle model which includes:

\section{risk ide ntification $\rightarrow$ risk de finition $\rightarrow$ ris $k$ evaluation $\rightarrow$ risk preparedness $\rightarrow$ risk response $\rightarrow$ risk mitigation}

The project final aim is to foster the level of urban governance in two world heritage sites by introducing an adequate policy to prevent or mitigate the effects of conflicts on the ancient/historic sites making use of a regional/urban planning method. The approach followed has driven to a review of:

- $\quad$ existing urban plans, regulatory policies and land use;

- legislation in place and missing regarding heritage, urban policies, defence;

- type of civil military pattern of relation at national and local level;

- civil protection/defence mechanism adopted in both countries;

- environmental conditions representing a factor of interest in case of military operation in the world heritage sites areas for the definition of buffer zones as appropriate;

- identification and analysis of existing structures and infrastructures suspected to be of any possible military strategic interest; etc.

The risk assessment took into account the above and other similar factors that were studied within a civil military cooperation perspective keeping in mind that both in times of peace and in times of war the military abide only with the policies set by their referents higher in command and especially with rules of engagement received for the specific 
theatre of conflict. The data and information collected after ground studies and several desk reviews were elaborated within the framework of organised multidisciplinary thematic groups.

The acquisition of the information needed to rationalise what type of risks are there and to estimate what kind of response would be necessary and more appropriate - per se - could help define generally valid instruments to manage risks in the event of armed conflicts. However, preparing for a more scientific insight and - in excess or in defect of data about the quality / quantity of threat identified, the capacity of response to protect heritage in times of conflict could be limited as far as for the definition of the existing risks factors and their interrelated values, threats are estimated more at an inductive level than based on scientific data analysis and elaboration. To address this aspect, the information acquired will be turned into alphanumeric data and elaborated according to set criteria in cooperation with specialised academies and research centres that are associates in the project. Data that will integrate comprehensive Risk Preparedness Plans to be implemented both in time of peace or in time of conflict according to set appropriate measures and protocols of interventions. Plans that will be finally incorporated within the ordinary site management procedures provided of mechanisms of updating and upgrading.

\section{CIVIL MILITARY COOPERATON ISSUES}

The very peculiar nature of the project and time constraints impose a close cooperation with and, at times, a rapid exchange of information from military, police, customs, border police and civil protection. Thus, upon prior agreement and formal invitation direct to their respective institutions, officers from various bodies were requested to work closely within a multidisciplinary and international experts' group set for the project. This kind of development was facilitated thanks to the establishment of an international Advisory Board set to support and backstop the project. In the Board join also representatives from the International Institute of Humanitarian Law and the Austrian Army. Both institutions assigned to the $\mathrm{AB}$ two high ranking officials with profound experience in Humanitarian law and Cultural Heritage protection in war theatre associated to international peace keeping operations. Their presence in the project helped to establish the right ground and mutual trust for a constructive cooperation with their colleagues from the two beneficiary countries.

The Civil Military Cooperation established within the project is a really an essential component to secure its development and the achievement of concrete results. Initially, it was not at all evident that national military experts would have contributed to the best of their knowledge in the implementation of activities. Instead, thanks also to the AB they actually cooperated and often proposed solutions that would have been hard to find exclusively based on a civil experts' perspective.

\section{NGOS AND HAGUE CONVENTION}

The 1954 Hague Convention for the Protection of Cultural Property in the event of Armed Conflict and its first Protocol remained widely not-applied especially due to the lack of more specific regulatory instruments and guidelines. The comprehensive review conducted in 1993 of the Convention and its limitations identified the weaknesses and the improvements required to ensure the application of more effective measures to secure the protection of cultural heritage during armed conflicts. Meanwhile, the same review highlighted the important role that should be played by NGOs and other civil society organisations in the implementation of the Convention*

War Free World Heritage Listed Cities was welcomed as bottom up initiative since the proposal was born as an expression of the responsible attempts made by local authorities to have a better understanding of the dimensions of the problems faced in recent conflicts for the protection of listed cultural heritage laying within their administrative boundaries in recent conflicts. This initiative presents several original elements that would need to be stressed especially associated to a consistent willingness to undertake the necessary measures to reduce the existing or pending threats should these cultural heritage sites become a military target during armed conflicts. A consistent will is shown by these local authorities to intervene vis-a-vis the threats posed to heritage sites that in addition to be important for their intrinsic cultural values also represent a primary opportunity for the development of their territories. In addition, a pattern of civil military cooperation is established since the early project formulation stage to secure the necessary level of appropriation of the results achieved as a matter of sustainability of the initiative.

The project was conceived, designed and is being implemented with the spirit typical of an international cooperation initiative confirming the value that is associated to World Heritage well above the national borders of the candidate countries. It should be however highlighted that in general it was registered also a positive response from most concerned national institutions and their willingness to participate to initiatives promoted by local authorities. However, institutional changes at Governmental level caused often delay and lower support to the project. Situation that could be addressed thanks to the direct involvement of the civil society representatives engaged within the project coordination team who took often the initiative to gather the necessary attention by the concerned institutions. Institutional instability, changes or weakness represent one of the factors of threats posed to cultural heritage as vacuums in decision making prevent the deployment of appropriate protective measures. This is why WFHLC project also addresses the following components:

\section{INSTITUTIONAL CAPACITY DEVELOPMENT}

To secure that by the end of the project will exist both in Lebanon and Georgia the necessary elements of sustainability since the beginning of the project relevant national and local authorities, target groups and stakeholders were the focus of direct and indirect actions. At the end of the project those main actors identified, trained and organised in mixed multidisciplinary work group were expected to integrate/ support a Risk Management Unit created to secure the implementation and constant upgrading of the Risk Preparedness Plans within the framework of an interinstitutional cooperation between the relevant institutions responsible to maintain the safety conditions stipulated in the 1999HP.

\footnotetext{
* Patrick, J. BOYLAN. Review of the Convention for the Protection of Cultural Property in the Event of Armed Conflict (Chapter 7 point 17.1 and following). (C) 1993 Boylan. Department of Arts Policy and Management, City University, Frobisher Crescent, Barbican, London EC2Y 8HB
} 
The status of enhanced protection is granted to the eligible heritage and it is maintained if the conditions stipulated especially under article 10a, 10b and 10c of the $1999 \mathrm{HP}$ are respected. Failure to observe those conditions could drive to the withdrawal of the enhanced protection (art.13 - 1999HP). This is why, ex-post project implementation periodic independent M\&E of the sites could be conducted based on the criteria set within the Risk Preparedness Plans, to secure that no threat is affecting the sites after the status of enhanced protection is eventually granted.

Risk Management Units (RMU) are currently being set and they will be joined by selected national experts from institutions. involved in the implementation of the Convention, Harmonisation of procedures, Set protocols of intervention for response to various types of alerts, etc. Introductory training modules will be delivered to members selected from but not limited to: the Ministry of Culture, Ministry of Defence, Ministry of Interiors and Local Authorities to integrate the first RMU group. The process to set this very specific training initially implied to gather the following information and products:

1. Training needs analysis,

2. Training Planning,

3. Specialised training supporting materials \& programs,

4. Criteria of evaluation (in progress and final).

\section{PUBLIC AWARENESS AND VISIBILITY ì}

The promotion of public awareness is foreseen since the early conception of the project. Awareness in considered to be one of the priorities up to the point that in certain countries public awareness is promoted even through printing thematic maps that are widely circulated of locations that are under protection. Civilians normally reacted positively in past experiences providing support and at times sheltering heritage when war on the ground went out of control of authorities. Of course not to mention the case of protection in case of asymmetric conflicts when irregular and often non better identified armed forces enter in action in areas with fragile levels of government. Than a well prepared Risk Preparedness Plan could spare total destruction or loss of at least the movable heritage when it coexist in world heritage sites. Public awareness could also be helpful to warn the hostile parties about the importance of listed world heritage for humanity as it maybe that informal armed forces are not informed that also they go subject to the provisions of the International law and especially the Hague Convention and its Protocols.

\section{LESSONS LEARNED AND ADJUSTMENTS NEEDED}

We are all aware of the great risks posed to heritage laying on sites turned into war theatres either international either local. The initiative presented within this paper represents an effort to pass from theory into practice the principles too often neglected that are enunciated in the Hague Convention and its Protocols.

Through this experience we learned and keep learning what factors can facilitate and what can definitely jeopardise the implementation of concrete risk preparedness, response and mitigation measures that can help contrast the effects produced by warfare when the ground is left out of institutional control and cultural heritage is left hostage as much as are innocent civil populations in a conflict.

The list of lessons learned during the past three and half years of work is long and will be soon published as part of WFWHLC project contribution. There are however, a few lessons learned that must be highlighted here and must be widely circulated to the concerned community and especially to those who wish to initiate the process to nominate to enhanced protection a movable or immovable heritage.

1. A participatory approach between public institutions (e.g. Ministries such as those of Culture, Defence, Interiors, Local Authorities) and the Civil Society (e.g. NGOs, Associations, Professional organisations) is possible only if a strong commitment is stipulated, since the beginning, within a formal agreement between all the main actors. Failure to gather this agreement will be surely cause of serious delays or in some case even the cancellation of the initiative.

2. National legislative framework must be deeply verified and eventually reviewed to secure that it is consistent to the provisions of the 1999HP.

3. Adequate Risk Preparedness, Response and Mitigation plans set and made operative for the heritage sites, including preventive measures to, at least, contrast the effects of floods, earthquakes and fire must be in place.

4. To prevent duplications and maximise the use of the often already limited resources available, the definition of a risk preparedness strategy for any sites should build on and incorporate already existing risk management plans implemented by Civil Defence or Civil Protection agencies most likely operating in the area.

5. Proper administrative measures for the heritage should be in place and incorporated in a site management plan that should include all the measure for safe visit by visitors, adequate work environment for properly trained personnel, etc.. Unfortunately, most of the time site management plans for movable and/or immovable heritage are weak and outdated, when available. Personnel did not receive proper training and is demotivated, and the overall level of management is poor, equipment when available is often outdated and their use limited.

6. The Enhanced Protection granted to movable and immovable heritage in application of the 1999HP is not merely a matter of legal status but rather a unique opportunity to properly manage movable and immovable heritage. To make it work however, it needs that all the involved parties are efficiently performing their tasks. This is why the creation of Risk Management Units responsible to coordinate protective measures for cultural heritage under extreme conditions represent a key issue to be address.

7. An RMU supported by a National Committee of the Blue Shield should be created, if not yet available, to complete the management circle and secure sustainability of protective measures designed per each heritage under enhanced protection. 